\title{
Patient's Knowledge of Medications Misadventure Information in Saudi Arabia
}

\author{
Yousef Ahmed Alomi ${ }^{1, *}$, Dima Ahmad Alaskari ${ }^{2}$, Malak Mohammad Almelfi ${ }^{2}$, Dima Ali Badawi ${ }^{3}$, Abdullah \\ Mohammad Alshihri ${ }^{4}$ \\ ${ }^{1}$ The Past General Manager of General Administration of Pharmaceutical Care and The Past Head, National Clinical Pharmacy \\ and Pharmacy Practice and Pharmacy $R$ and D Administration, Ministry of Health, Riyadh, SAUDI ARABIA. \\ ${ }^{2}$ General Administration of Pharmaceutical Care, Ministry of Health, Riyadh, SAUDI ARABIA. \\ ${ }^{3}$ Pharmaceutical Care Services, Saudi Germany Hospital, Aseer, SAUDI ARABIA. \\ ${ }^{4}$ Head, Pharmaceutical Care Services, Abha Maternity and Children Hospital, Abha, SAUDI ARABIA.
}

\section{Received: 02 June 2018; \\ Accepted: 28 August 2018 \\ *Correspondence to: \\ Dr. Yousef Ahmed Alomi,}

The Past General Manager of General Administration of Pharmaceutical Care, The Past Head, National Clinical pharmacy and pharmacy practice The Past Head, Pharmacy $R$ and D Administration Ministry of Health, P.O.BOX 100, Riyadh 11392, Riyadh, SAUDI ARABIA.

Email:yalomi@gmail.com

Copyright: (c) the author(s),publisher and licensee Indian Academy of Pharmacists. This is an open-access article distributed under the terms of the Creative Commons Attribution Non-Commercial License, which permits unrestricted non-commercial use, distribution, and reproduction in any medium, provided the original work is properly cited.

\begin{abstract}
Objective: To explore the Patient's Knowledge of Medications Misadventure Information in Saudi Arabia. Methods: It is a 4-months cross-sectional survey of patient and Drug-related problem information in Saudi Arabia. The survey consisted of two-part, demographic data and second part forty-nine questions divided into four domains. It included domain 1: necessary information about patient medication, domain 2: patient information about the drug-related problem, domain 3: patient information about drug-related cost and domain 4: patient perception of medications. Midline Plus health information and DailyMed elements information from National Institute of Health United State of America used. The 5-point Likert response scale system was used. The survey was distributed through social media and at 500-bed pediatrics and maternity hospital in Asir region, at ambulatory care pharmacy. The authors did the patients interview with electronic survey documentation. The survey was made in an electronic format and it analyzed domain two through survey monkey system. Results: The total responders were (614) Saudi patient, the gender distribution $523(86.7 \%)$ were females and $91(13.3 \%)$ were males. The majority of them in age (18-44) 78.3\% and located at Asir region 325 (115\%) and Riyadh region 163 (46.9\%). The responders showed no adequate knowledge either complete or incomplete information about the adverse drug reaction either a general side effect of medications 343 (58.5\%) only or potential adverse event about their medications 295 (51.2\%). The responder showed that they are not aware of contraindication of medicines used with other diseases condition 253 (43.2\%), drugs 264 (45.4\%), food 277 (47.6\%) or laboratory test $285(49.5 \%)$ and $320(55.4 \%)$ with the herbal drug. The responders showed no adequate knowledge either complete or incomplete information about usage of medications for children 322 (56.46\%) or elderly 301 (51.45\%), drug use during pregnancy 329 (56.52\%) or breastfeeding 319 (54.71\%). Conclusion: More than fifty percent of the patients were not familiar with the essential drug-related problems information. It is potential to drug misadventures and cost burden in the society. Very comprehensive and urgent implementation of the patient medications education program in Saudi Arabia is needed.
\end{abstract}

Key words: Patient, Knowledge, Misadventure, Medications, Ministry of Health, Saudi Arabia.

\section{INTRODUCTION}

A drug-related problem (DRP) defined as an event or circumstance involving drug therapy that actually or potentially interferes with the desired health outcome. ${ }^{[1]}$ The drug-related problem prevention as part of pharmaceutical care services provided to the patients. ${ }^{[2]}$ The drug-related problem included eight problems including medications errors, adverse drug retraction, a drug without indication, indication without medications, medication noncompliance, drug interaction, failed to receive medications and drug poisoning. ${ }^{[2-3]}$ Drug-related problems are most common in patients taking more than one drug at the same time, patients with chronic illnesses or elderly patients were found to use about three times more drugs than younger patients. ${ }^{[4]}$ Some studies have identified different risk factors for developing at least one DRP in patients with cardiovascular diseases and the use of multiple medications is one of the variables most commonly identified ${ }^{[1]}$ The pharmacists should check with work patient and other medical team members to prevent during drug therapy. The patient has to get drug information and knowledge of drug-related problems may occur or how to deal with them if they occur. Several studies investigated the patient's medication knowledge including drug-related problems among them. $\cdot^{[5-8]}$ Also, all the studies discussed a specific group of medications. There is no study discussed drug-related knowledge with patients. It is hard to find local studies or Gulf and Middle East counties about patient's drug-related problems knowledge. The goal of the study was to explore the patient's drug-related knowledge in Kingdom of Saudi Arabia. 


\section{METHODS}

It is a 4-months cross-sectional survey of patient and basic knowledge of medicines. The survey consisted of two-part, demographic information and second part forty-nine questions divided into four domains. It included domain 1: Primary or essential information about patient medication, domain 2: patient information about the drug-related problem, domain 3: patient information about drug-related cost and domain 4: patient perception of medications. Medline Plus health information and DailyMed-INH elements information from National Institute of Health United State of America were used. ${ }^{[9-10]}$ The 5 -point Likert response scale system was used. The questions were open and closed-ended. The survey was distributed through social media and at 500-bed pediatrics and maternity hospital in Asir region, at ambulatory care pharmacy. The hospitals were accredited by Saudi Center for Healthcare organization (CBAHI) and Joint Commission on Hospital Accreditation from the United States of America (USA). ${ }^{[1-12]}$ The hospital's several departments were included such as Pediatrics, Obstetrics and Gynecology. It had Adults, Pediatrics and Neonatal critical care, with the separated nursing unit. In addition to medical and surgical sections for adults, pediatrics and neonates. The pharmacy departments distributed the medication through unit dose system according to CBAHI standards and American Society of Health-System standards. Also, the pharmacy had inpatient pharmacy, outpatient pharmacy, Intravenous Admixture services with professional Total Parenteral Nutrition. The clinical pharmacy services did not entirely exist except some programs for an instant; drug information center, patient-counseling services and medication safety program. The authors did the patients interview with electronic survey documentation. The survey was made in an electronic format and it analyzed domain two patient information about the drug-related problem through survey monkey system.

\section{RESULTS}

The total responders were (614) patients with Saudi $564(96.1 \%)$ and Non-Saudi $23(3.9 \%)$ nationalities. The gender distribution $523(85.2 \%)$ were females and $91(14.8 \%)$ were males. The majority of them in age (18-44) 78.3\% and located at Asir region 325 (52.93\%) and Riyadh region 163 (26.54\%). The most patients had the Bachelor Degree 311 (50.65\%) followed by High school 138 (22.48\%) and Diploma 47 (7.65\%). The most type of medications used was anti-diabetic and anti-hypertension medicines, Skin medications and drugs for Respiratory Diseases. Also, the total patient currently taking medication were 249 (43.23\%). Of those the most number of medication taken either one 96 (38.55\%), two medications $79(31.73$ $\% \%$ ), three medications $25(10.04 \%)$ and four medications $24(10.04 \%)$ as explored in Table 1 . The responders showed no adequate knowledge either complete or incomplete information about the adverse drug reaction either a general side effect of medications $343(58.5 \%)$ only or potential adverse events about their medications 295 (51.2\%). More than half of responders were not familiar with drug overdose behaving 377 (64.1\%) or first aid of drug poisoning $381(65.2 \%)$ as explored in Table 2 . The responder showed not aware of contraindication of medicines used with other diseases condition $253(43.2 \%)$, drugs 264 (45.4\%), food 277 (47.6\%) or laboratory test $285(49.5 \%)$ and $320(55.4 \%)$ with the herbal drug as explored in Table 3. The responders showed not adequate knowledge either complete or incomplete information about the use of medications for children 322 $(56.46 \%)$ or elderly $301(51.45 \%)$, drug use during pregnancy $329(56.52 \%)$ or breastfeeding $319(54.71 \%)$. Moreover, during exercises $258(44.56 \%)$ or practicing the job $270(46.4 \%)$ as explored in Table 4.

\section{DISCUSSION}

The pharmacy administration at Ministry of health established several programs within pharmaceutical care department around hospitals and primary care center to prevent drug misadventures and complicated related

\begin{tabular}{|c|c|c|}
\hline Characteristics & Response N & Response \% \\
\hline \multicolumn{3}{|l|}{ Sex } \\
\hline Female & 523 & $85.2 \%$ \\
\hline Male & 91 & $14.8 \%$ \\
\hline Answered question & 614 & $100 \%$ \\
\hline Skipped question & 0 & \\
\hline \multicolumn{3}{|l|}{ Nationality } \\
\hline Saudi & 564 & $96.1 \%$ \\
\hline Non-Saudi & 23 & $3.9 \%$ \\
\hline Answered question & 587 & $100 \%$ \\
\hline Skipped question & 27 & \\
\hline \multicolumn{3}{|l|}{ Age } \\
\hline$<18$ & 34 & $9.9 \%$ \\
\hline $18-29$ & 267 & $103.0 \%$ \\
\hline $30-44$ & 214 & $60.9 \%$ \\
\hline $45-59$ & 87 & $22.5 \%$ \\
\hline $60+$ & 12 & $3.6 \%$ \\
\hline Answered question & 614 & $100 \%$ \\
\hline Skipped question & 0 & \\
\hline \multicolumn{3}{|l|}{ Total Experiences } \\
\hline Doctorate degree & 7 & $1.14 \%$ \\
\hline Master degree & 17 & $2.77 \%$ \\
\hline Bachelor Degree & 311 & $50.65 \%$ \\
\hline Diploma & 47 & $7.65 \%$ \\
\hline High school & 138 & $22.48 \%$ \\
\hline Intermediate School & 33 & $5.37 \%$ \\
\hline Primary School & 27 & $4.40 \%$ \\
\hline Not educated & 34 & $5.54 \%$ \\
\hline Answered question & 614 & $100 \%$ \\
\hline Skipped question & 0 & \\
\hline \multicolumn{3}{|l|}{ The current medications } \\
\hline Diabetic Medication & 79 & $12.91 \%$ \\
\hline Antihypertensive Medication & 64 & $10.46 \%$ \\
\hline Cardiac Medication & 13 & $2.12 \%$ \\
\hline Asthma Medication & 50 & $8.17 \%$ \\
\hline Derma Medication & 57 & $9.31 \%$ \\
\hline Anti-Rheumatic & 32 & $5.23 \%$ \\
\hline Do not take anything now & 412 & $67.32 \%$ \\
\hline Others & 87 & $14.22 \%$ \\
\hline Answered question & 612 & $100 \%$ \\
\hline Skipped question & 2 & \\
\hline \multicolumn{3}{|c|}{ Number of current medication taken } \\
\hline Nothing & 327 & $56.77 \%$ \\
\hline 1 & 96 & $38.55 \%$ \\
\hline 2 & 79 & $31.73 \%$ \\
\hline 3 & 25 & $10.04 \%$ \\
\hline 4 & 24 & $9.64 \%$ \\
\hline 5 & 13 & $5.22 \%$ \\
\hline 6 & 5 & $2.01 \%$ \\
\hline 7 & 3 & $1.20 \%$ \\
\hline 8 & 0 & $0.00 \%$ \\
\hline 9 & 1 & $0.40 \%$ \\
\hline 10 & 2 & $0.80 \%$ \\
\hline more than 10 & 0 & $0.00 \%$ \\
\hline Answered question & 576 & \\
\hline Skipped question & 38 & \\
\hline
\end{tabular}


Alomi, et al.: Study about drug information problems among healthcare professionals

\begin{tabular}{|c|c|c|c|c|c|c|c|c|}
\hline No. & Answer Options & $\begin{array}{l}\text { Complete } \\
\text { information }\end{array}$ & $\begin{array}{l}\text { Incomplete } \\
\text { information }\end{array}$ & $\begin{array}{l}\text { Weak } \\
\text { information }\end{array}$ & $\begin{array}{l}\text { I do not } \\
\text { have } \\
\text { information }\end{array}$ & $\begin{array}{l}\text { I do not } \\
\text { need this } \\
\text { information }\end{array}$ & $\begin{array}{l}\text { Rating } \\
\text { Average }\end{array}$ & Response N \\
\hline 1 & $\begin{array}{l}\text { The adverse drug reaction } \\
\text { information }\end{array}$ & 200 & 143 & 82 & 126 & 35 & 3.59 & 586 \\
\hline 2 & $\begin{array}{l}\text { The potential or dangerous } \\
\text { adverse drug reaction }\end{array}$ & 162 & 133 & 93 & 147 & 41 & 3.40 & 576 \\
\hline \multicolumn{9}{|c|}{ answered question:588 and skipped question: 26} \\
\hline \multicolumn{9}{|c|}{ The overdose or poisoning management information on medications used } \\
\hline & Answer Options & $\begin{array}{l}\text { Complete } \\
\text { information }\end{array}$ & $\begin{array}{l}\text { Incomplete } \\
\text { information }\end{array}$ & $\begin{array}{l}\text { Weak } \\
\text { information }\end{array}$ & $\begin{array}{l}\text { I do not } \\
\text { have } \\
\text { information }\end{array}$ & $\begin{array}{l}\text { I do not } \\
\text { need this } \\
\text { information }\end{array}$ & $\begin{array}{l}\text { Rating } \\
\text { Average }\end{array}$ & $\begin{array}{l}\text { Response } \\
\text { Count }\end{array}$ \\
\hline 1 & $\begin{array}{l}\text { The information of facing of drug } \\
\text { overdose or poisoning }\end{array}$ & 62 & 118 & 113 & 264 & 31 & 2.86 & 588 \\
\hline 2 & $\begin{array}{l}\text { The first aid when poisoning } \\
\text { occurs }\end{array}$ & 51 & 121 & 116 & 265 & 31 & 2.82 & 584 \\
\hline
\end{tabular}

\begin{tabular}{|c|c|c|c|c|c|c|c|c|}
\hline No. & Answer Options & $\begin{array}{l}\text { Complete } \\
\text { information }\end{array}$ & $\begin{array}{l}\text { Incomplete } \\
\text { information }\end{array}$ & $\begin{array}{l}\text { Weak } \\
\text { information }\end{array}$ & $\begin{array}{l}\text { I do not } \\
\text { have } \\
\text { information }\end{array}$ & $\begin{array}{l}\text { I do not } \\
\text { need this } \\
\text { information }\end{array}$ & $\begin{array}{l}\text { Rating } \\
\text { Average }\end{array}$ & Response N \\
\hline 1 & $\begin{array}{l}\text { The usage of medications with } \\
\text { diseases are forbidden }\end{array}$ & 163 & 121 & 90 & 163 & 48 & 3.32 & 585 \\
\hline 2 & $\begin{array}{l}\text { The use of medication with } \\
\text { other drugs are forbidden }\end{array}$ & 138 & 130 & 89 & 175 & 50 & 3.23 & 582 \\
\hline 3 & $\begin{array}{l}\text { The use of medicines in certain } \\
\text { foods are forbidden }\end{array}$ & 128 & 129 & 98 & 179 & 48 & 3.19 & 582 \\
\hline 4 & $\begin{array}{l}\text { The use of medicines with } \\
\text { Laboratory tests are forbidden }\end{array}$ & 130 & 112 & 83 & 202 & 49 & 3.13 & 576 \\
\hline 5 & $\begin{array}{l}\text { The use of medicines with herbs } \\
\text { are forbidden }\end{array}$ & 79 & 119 & 81 & 239 & 60 & 2.86 & 578 \\
\hline
\end{tabular}

\begin{tabular}{|c|c|c|c|c|c|c|c|c|}
\hline No. & Answer Options & $\begin{array}{l}\text { Complete } \\
\text { information }\end{array}$ & $\begin{array}{l}\text { Incomplete } \\
\text { information }\end{array}$ & $\begin{array}{l}\text { Weak } \\
\text { information }\end{array}$ & $\begin{array}{l}\text { I do not } \\
\text { have } \\
\text { information }\end{array}$ & $\begin{array}{l}\text { I do not } \\
\text { need this } \\
\text { information }\end{array}$ & $\begin{array}{l}\text { Rating } \\
\text { Average }\end{array}$ & Response N \\
\hline 1 & $\begin{array}{l}\text { The medication used for } \\
\text { children }\end{array}$ & 189 & 143 & 88 & 106 & 62 & 3.49 & 588 \\
\hline 2 & $\begin{array}{l}\text { The medication used for } \\
\text { elderly }\end{array}$ & 143 & 158 & 112 & 106 & 66 & 3.35 & 585 \\
\hline 3 & $\begin{array}{l}\text { The medication used for } \\
\text { pregnancy }\end{array}$ & 219 & 110 & 71 & 88 & 94 & 3.47 & 582 \\
\hline 4 & $\begin{array}{l}\text { The medication used for } \\
\text { breast feeding }\end{array}$ & 192 & 127 & 71 & 88 & 105 & 3.37 & 583 \\
\hline 5 & $\begin{array}{l}\text { The medication used for } \\
\text { sport }\end{array}$ & 108 & 150 & 108 & 141 & 72 & 3.14 & 579 \\
\hline 6 & $\begin{array}{l}\text { The medication used for } \\
\text { practicing job }\end{array}$ & 122 & 148 & 98 & 139 & 75 & 3.18 & 582 \\
\hline
\end{tabular}


issues. ${ }^{[13]}$ The prevention started at patient's home during patient medications counseling during discharge from the hospital or ambulatory care visiting. Also, during the emergency visit or hospital admission or transfer from upper to lower hospital facilities through medications reconciliation program. The pharmacist provides primary medications education session to all patients during National Diabetic or National Asthma or National psychiatric awareness days. ${ }^{[14]}$ The education courses were part of the patient counseling program. All those programs will strength background medication knowledge of the drug-related problem and subsequently prevent drug-related problems. The actual background or knowledge of patient is not well known in Saudi Arabia. The author wishes to evaluate the current knowledge of drug-related problems with patients in Kingdom of Saudi Arabia. The results of patient and drug-related knowledge information were inadequate that included advesre drug reaction, drug overdose information or first aid of drug poisoning. In addition to contradicted informatics with medication and disease or drugs or, food lab test or herbal medication. That is related to patient education about medications at Ministry of Health organizations is not well competed and pharmacy public education is absent most of the time. The results are better than what reported by other study. The finding of use of medications during a unique situation like pediatric or geriatrics or pregnancy and breastfeeding and practice exercises or jobs is not adequate due to same previous reason. ${ }^{[5,7]}$ Those results could not compare with them; most of the studies did not discuss these issues. Further studies about patients and drug-related problems in Kingdom of Saudi Arabia are highly recommended.

\section{CONCLUSION}

Missing knowledge of the drug-related problems can implicate to occur with cost and effort burden in the society. Educating the patient of drug-related problems reduces risk. It is also essential to educate and train the medical staff to avoid such problems. It is also possible that early detection of harmful drug interactions will help to reduce problems related to drug therapy.

\section{ACKNOWLEDGMENT}

None

\section{CONFLICT OF INTEREST}

None

\section{ABBREVIATIONS}

KSA: Kingdom of Saudi Arabia; MOH: Ministry of Health; CBAHI: Saudi

Center for Accreditation of Healthcare Institutions.

\section{REFERENCES}

1. Urbina O, Ferrández O, Luque S, Grau S, Mojal S, Pellicer R, et al. Patient risk factors for developing a drug-related problem in a cardiology ward. Ther Clin Risk Manag. 2015;11:9-15.

2. American Society of Hospital Pharmacists. ASHP Statement on Pharmaceutical Care. Am J Hosp Pharm. 1993;50:1720-3.

3. Van DBPM, Egberts TC, Jong-van DDBerg LT, Brouwers JR. Drug-related problems in hospitalized patients. Drug Saf. 2000;22(4):321-33.

4. Vinks THAM, Koning FHP, Lange TM, Egberts TCG. Identification of Potential Drug-related Problems in the Elderly: The Role of the Community Pharmacist. Pharm World Sci. 2006;28(1):33-8.

5. Williams L, Caskey H, Coates V, Thompson K, Helen S. A survey of patients' knowledge of their diabetes medication. J Diabetes Nurs. 2007;11(7):264-9.

6. Jodlowski TZ, Sym D, Conry J, Kanmaz T. Antiretroviral medication knowledge among New York State pharmacists: room for improvement. J Pharm Pract. 2010;23(5):507-10.

7. Rubio JS, García DP, Iglésias FP, Mateus SH, Martínez MF. Measurement of patients' knowledge of their medication in community pharmacies in Portugal. Cien Saude Colet. 2015;20(1):219-28.

8. Zaki NM, Albarraq AA. Use, attitudes and knowledge of medications among pregnant women: A Saudi study. Saudi Pharm J. 2014;22(5):419-28.

9. MedlinePlus - Health Information from the National Library of Medicine. Available from: https://medlineplus.gov/

10. DailyMed. Available from: https://dailymed.nIm.nih.gov/dailymed/

11. Medication Management (MM). In: National Hospital Standards. $2^{\text {nd }}$ Ed. Saudi Central Board for Accreditation of Healthcare Institutions. 2015;194-211.

12. Comprehensive Accreditation Manuals. Joint Commission Resources. Available from: http://www.jcrinc.com/store/publications/manuals/

13. Alomi YA, Alghamdi SJ, Alattyh RA. Strategic Plan of General Administration of Pharmaceutical Care at Ministry of Health in Saudi Arabia 2012-2022. J Pharm Pharm Sci. 2015;1(3):1-8.

14. Alomi YA, Alghamdi SJ, Alattyh RA, Alshahrani AM, Shorog EM, Alasmary SA, et al. National Survey Of Pharmacy Practice At Moh Hospitals In Saudi Arabia 2016: Drug Monitoring And Patient Education. In: Value In Health. 2017;A36-A36. 